IZA DP No. 4819

The Intergenerational Transmission of Employers

Miles Corak

Patrizio Piraino

March 2010 


\title{
The Intergenerational Transmission of Employers
}

\author{
Miles Corak \\ University of Ottawa \\ and IZA \\ Patrizio Piraino \\ Statistics Canada
}

\author{
Discussion Paper No. 4819 \\ March 2010
}

IZA

P.O. Box 7240

53072 Bonn

Germany

Phone: +49-228-3894-0

Fax: +49-228-3894-180

E-mail: iza@iza.org

Any opinions expressed here are those of the author(s) and not those of IZA. Research published in this series may include views on policy, but the institute itself takes no institutional policy positions.

The Institute for the Study of Labor (IZA) in Bonn is a local and virtual international research center and a place of communication between science, politics and business. IZA is an independent nonprofit organization supported by Deutsche Post Foundation. The center is associated with the University of Bonn and offers a stimulating research environment through its international network, workshops and conferences, data service, project support, research visits and doctoral program. IZA engages in (i) original and internationally competitive research in all fields of labor economics, (ii) development of policy concepts, and (iii) dissemination of research results and concepts to the interested public.

IZA Discussion Papers often represent preliminary work and are circulated to encourage discussion. Citation of such a paper should account for its provisional character. A revised version may be available directly from the author. 


\section{ABSTRACT}

\section{The Intergenerational Transmission of Employers ${ }^{\star}$}

We find that about $40 \%$ of a cohort of young Canadian men has been employed with an employer for whom their father also worked; and six to nine percent have the same employer in adulthood. The intergenerational transmission of employers is positively related to paternal earnings, particularly at the very top of the earnings distribution, and to the presence of selfemployment income and the number of employers with which the father has had direct contact. It has an important influence in determining nonlinear patterns in the intergenerational elasticity of earnings.

JEL Classification: J62, J64

Keywords: intergenerational mobility, job search

Corresponding author:

Miles Corak

Graduate School of Public and International Affairs

University of Ottawa

Desmarais Building, Room 11156

55 Laurier Avenue East

Ottawa, Ontario K1N 6N5

Canada

E-mail: corak@iza.org

\footnotetext{
* This is a revised version of a paper presented to the MILLS Workshop in Milan Italy in June 2009; the Annual Conference of the Canadian Economics Association held in Toronto, Canada in May 2009; the Society of Labor Economists $14^{\text {th }}$ Annual Meetings held in Boston, United States in May 2009; the "Brucchi-Luchino" labour economics workshop held at Bologna, Italy in November 2008; the $30^{\text {th }}$ conference of the International Association for Research in Income and Wealth held at Portoroz, Slovenia in August 2008; the "Intergenerational Mobility Conference" organized by the Centre for Longitudinal Studies and the Centre for the Economics of Education held at the London School of Economics in June 2008, London, UK; and the conference on "Recent Developments in Research on Intergenerational Mobility" organized by the Scottish Institute for Research in Economics and held at the University of Edinburgh, Edinburgh, UK also in June 2008. We thank the participants as well as those attending departmental seminars at McGill University, McMaster University, University of Milan, University of Ottawa, University of Warwick and the University of Waterloo for their feedback. In particular we acknowledge suggestions and comments from Carlo Fiorio, Markus Jäntti, Sandra McNally, Robin Naylor, Lars Osberg, Krishna Pendakur, and Anindya Sen. We also appreciate help during the early stages of constructing the data from Leonard Landry, Darren Lauzon, Sophie Lefebvre, and Debbie Tobalt, and the advice of Mikal Skuterud. Corak acknowledges financial support from the Social Sciences and Humanities Research Council of Canada.
} 


\section{The Intergenerational Transmission of Employers}

\section{Introduction}

The nature and extent of the relationship between the adult success of children and their family background is of longstanding interest in the social sciences and public policy. In large part this reflects the idea that the strength of the tie between parent and child outcomes is an interesting characterization of a society, revealing the degree to which inequality is transmitted across the generations and in a broad sense speaking to the notion of equality of opportunity. This interest motivates a literature in labour economics addressing the intergenerational relationship between parent and child earnings. The focus in this research, which is surveyed by Björklund and Jäntti (2009), Corak (2006) and Solon $(2002,1999)$, is on the accurate estimation of the intergenerational earnings elasticity in the context of a linear regression to the mean model. But as Roemer (2004) points out, on its own an intergenerational tie in the earnings of parents and children reveals little about the degree of equality of opportunity because it tells us little about the circumstances governing the types of advantages and investments passed on across the generations. On the one hand, it is often suggested that the explanation for these patterns involves the role of the family and public investments in promoting early childhood development. At the other extreme, it could well be that children resemble their parents because of nepotism in the hiring process determining access to good jobs. These are examples of the types of circumstances that are necessary to appreciate if we are to understand the significance of any given degree of intergenerational relationship in 
earnings. Public policy directed to the early years will not be as effective in promoting equality of opportunity if the ultimate access to jobs is also determined by informal networks or nepotism during the teen or young adult years.

We address this concern by using a large administrative data base on a cohort of young Canadian men to advance an argument that proceeds in three steps. First, we offer descriptive information on the degree to which employers are transmitted across the generations using two indicators addressing alternative perspectives on this process: the facilitation of job search through informational networks, and firm-specific investments made by parents in their children. We find that by their early 30s about four-in-ten sons have worked at least once for an employer who also employed their fathers. This is consistent with a long-established empirical literature showing that information from family and friends is the most common method of finding a job. In our data a significant fraction of this is associated with the first jobs that young people find during their teens and early twenties. However, we also document the fact that about six to nine percent of the individuals in our sample hold their main job as adults with the same main employer their fathers had some 15 to 20 years earlier. To the best of our knowledge this is the first economy-wide documentation of the intergenerational transmission of these types of employers. It offers general evidence on patterns that have been documented for specific sectors or occupations such as agriculture, law, and medicine. If there is merit to a firmspecific human capital explanation of these patterns then it is appropriate for somewhere between one-in-twenty to one-in-ten young men.

The second step in our argument is to more carefully address the determinants of these underlying patterns. By constructing a series of counterfactuals we show that these 
proportions are much higher than would be expected from a simple random allocation of sons across firms. We also show that they are consistent with the role of informational networks and firm specific attributes passed on between father and son—as measured by the number of employers with which the father has had contact — as well as with influence over the hiring process, as indicated by a strong relationship with paternal income and self-employment. The intergenerational transmission of employers is higher among sons whose fathers have higher earnings, but particularly among the top five percent and strikingly so among the top one percent of the earnings distribution. Almost $70 \%$ of the sons of top percentile fathers have at some point worked for a firm that also employed their fathers.

Finally, our analysis relates the intergenerational transmission of employers to the intergenerational transmission of earnings. We find that the inheritance of employers raises the average intergenerational earnings elasticity, but not by a large degree. The influence is stronger when we examine non-linearities in the intergenerational elasticity. The intergenerational transmission of employers varies across the paternal earnings distribution, and is strongly associated with non-linear patterns in the intergenerational elasticity of earnings which also rises sharply at the top of the paternal earnings distribution. This calls for a more detailed analysis of the way in which the transmission of employers influences intergenerational earnings dynamics, and in general suggests that in future research the inheritance of employers form part of the study of intergenerational earnings mobility.

2. Previous literature and measures of the intergenerational transmission of employers 
The intergenerational transmission of employers is, in the first instance, often thought to depend on the extent to which parents directly control the chances their children will receive a job offer, changing the rate of job offers from particular employers and raising the possibility of nepotism. This perspective suggests that the intergenerational transmission of jobs is more likely when fathers are self-employed, as examined by Lentz and Laband (1990) and Dunn and Holtz-Eakin (2000). In a similar way, fathers with higher earnings, and therefore possibly in positions with more autonomy and influence in the workplace, may also increase the likelihood their employers will extend a job offer to their sons. This is directly explored in a literature on the succession of CEOs as in PérezGonzález (2006) for the United States, and Bennedsen et al (2007) for Denmark. The incidence of family based succession - those in which the new CEO is related by blood or marriage to the departing $\mathrm{CEO}$, the founder, or a large shareholder - is high in these data, representing more than one-third of the slightly over 300 successions among publicly traded companies in the US data used by Pérez-González (2006).

While the intergenerational transmission of employers may very well be important for the children of the self-employed or very rich, it is likely to be more broadly based across the income and earnings distribution than this literature might suggest. It is well established that families and friends are important in the job search process. Granovetter (1995) is an often cited source documenting this in a small scale survey for a particular labour market, and Holzer (1988) explicitly models the choice of search methods underscoring the fact that family and friends represent a relatively productive and low cost way of obtaining job offers. These patterns are well established in nationally representative surveys with Loury (2006) suggesting that up to $50 \%$ of jobs 
in the United States are found through family, friends or acquaintances. Ioannides and Loury (2004) offer a detailed survey documenting this sort of networking. In Canada, Grenon (1999) reports that about one-quarter of successful job searches involve family or friends. Magruder (2010) also makes network effects the focus of his analysis of similarities in the industry of employment for fathers and sons in South Africa. Kramarz and Skans (2007) are even more specific concerning the nature of the contacts, pointing out that there is a high tendency for young adults in Sweden to find their first job in the same plant that employs their parent.

At the same time, there is also a literature on the intergenerational transmission of employers and occupations motivated less by job search theory than by models of firm or sector specific human capital investments that parents make in their children. The focus in this literature is on certain sectors, particularly the farming sector, where the development of very specific skills and knowledge among children plausibly implies that they will be more productive by inheriting the family farm than by working on other farms or in other sectors. Rosenzweig and Wolpin (1985) develop this theory and offer evidence on developing countries, while Kimhi and Nachlieli (2001), Laband and Lentz (1983), and McNally (2003) study the agricultural sector in rich countries. This model has also been applied to the tendency of the children of doctors, lawyers, and the selfemployed to be employed in the same occupations as their fathers (Laband and Lentz 1992, Lentz and Laband 1990, 1989). The interpretation of this process, however, is still open, with Polacheck (1986) not excluding the role of nepotism. But informative as this 
literature is, it remains addressed to specific sectors and professions and has not been empirically examined at an economy-wide level. ${ }^{1}$

The job search and firm specific human capital literatures lead us to define two complementary definitions of what it means to be employed by the same firm as one's parent. The first is a broad measure indicating whether an adult currently works, or worked at any point in the past, with the same employer who had also at some point employed his father. We present this measure to reflect the influence of parental networks on the child's job search. ${ }^{2}$ The second definition is more specific, referring to whether the individual's main employer in adulthood is the same as the main employer the parent had during the child's teen years. It is intended to reflect outcomes from firm-specific human capital investments made early in a child's life that may improve the job offer distribution more in certain firms or sectors associated with the father's place of work than in others. This requires a longer-term focus, and for this reason we examine the intergenerational transmission of the main employer the father had during the son's teen years and the main employer of the son in adulthood.

\section{Nature of the data}

\footnotetext{
${ }^{1}$ There is also a long literature in sociology dealing with the intergenerational transmission of occupations and its relationship to social class with some of the chapters in Morgan, Fields and Gursky (2006) offering recent examples. Jonsson et al (2009) encompass the various strands in this literature, which rarely refers to the transmission of employers. Their analysis of four countries does make reference to Japan as a case in which the transmission of occupations across the generations is mediated by the transmission of employers. ${ }^{2}$ There will be an understatement built into this for a number of reasons. First, fathers may have direct knowledge of firms, their locations, hiring practices, and the chances their sons may obtain an offer that does not depend upon having been employed with them. Second, the network upon which the son may rely extends beyond his father to other relatives including potentially those of his father-in-law. Finally, the son might never have been employed at any of the firms that ever employed his father even though the network exists and he may have had the opportunity. On the other hand, this life-cycle measure of same-firm employment may overstate the breadth of the father's network in the sense that the son could have found the job without relying upon the father.
} 
We use a large administrative data set for a cohort of young Canadians. Our analysis is based upon the Intergenerational Income Data (IID) we developed at Statistics Canada from administrative information on individual income tax returns that have been grouped into families. Canadians file their income tax returns (officially referred to as T1 Forms) on an individual basis, and Statistics Canada has grouped these into families using a variety of matching strategies that are described in Harris and Lucaciu (1994). The resulting T1 Family File is the basic building block for the creation of the IID, an intergenerationally linked set of T1 Forms for a series of cohorts of young men and women, and their mothers and fathers. This represents not quite four million individuals and their parents, and in particular 1.9 million men who are the starting point for our research. These individuals are linked to their fathers-not necessarily their biological fathers-if they filed an income tax return between 1982 and 1986 while still living at home. This is required to ensure that a parent-child match is made, and also that the child has an observed Social Insurance Number (SIN), a unique individual identifier that can then be used to link all subsequent T1 Forms which contain information on earnings. These T1 Forms are available for all years between 1978 and $1996 .{ }^{3}$ From this data we select the male cohort born in 1963, the oldest cohort of sons available to us (those who are 33 years old at the end of the sample period). The use of the oldest cohort simplifies some of the derivations, but also improves the quality of the derived measure of permanent earnings by focusing on the oldest part of the child's life cycle available to us.

\footnotetext{
${ }^{3}$ The algorithm used to create the data leads to an under-representation of children from lower income backgrounds, and from the major metropolitan areas: Montreal, Toronto, and Vancouver. Corak and Heisz (1999), Oreopoulos (2003), and Oreopoulos, Page and Stevens (2008) all explore the nature of this underreporting and find that it does not play a role in biasing their analytical results. We note that weights based upon Census data have been created to account for the under-reporting, and our analysis uses them throughout even though they make no difference to the results.
} 
Table 1 presents basic descriptive information. To remain in the sample the father must have positive earnings in each of the five years the son was 15 to 19 years old, and must have been born between 1908 and 1952 inclusive. Sons must have positive earnings in each of three years, 1994 to 1996, and the earnings of both sons and fathers must be above the bottom percentile thereby avoiding some suspected measurement errors in the data. The sample size is about 71,000 observations, representing 84,000 individuals when appropriately weighted. ${ }^{4}$ Fathers are on average in their mid forties when their earnings are calculated.

Versions of these data have been used by Blanden (2005), Corak (2001), Corak, Gustafsson, and Österberg (2004), Corak and Heisz (1999), Grawe (2006, 2004), and Oreopoulos (2003) to study a host of issues dealing with intergenerational mobility. Our use of the data is closest to that of Oreopoulos, Page and Stevens (2008) who represent the only other application that uses information on the specific firms employing parents. The fathers and sons are employed at 24,000 to 32,000 distinct employers. The identification of these employers is developed from a longitudinally consistent catalogue of all enterprises in the country, and linked to individuals through the earnings remittance forms issued to employees (the T4) and used to support their income tax returns. This database of firms is referred to as the LEAP. ${ }^{5}$ Each T4 has a payroll deduction account

\footnotetext{
${ }^{4}$ By imposing these restrictions we are attempting to minimize the role of measurement error in earnings, as stressed in the literature on intergenerational earnings mobility (Solon 1992, 1989) Our selection rules correspond to Corak and Heisz (1999) who suggest that averaging over five years is long enough to minimize the rule of transitory earnings fluctuations in these Canadian data. This restriction has the greatest impact in determining the analytical sample. In the analysis that follows we check the robustness of our results by also using a sample in which the father is required to have only one year of positive earnings. ${ }^{5}$ The acronym refers to Longitudinal Employment Analysis Program. See Statistics Canada $(1992,1988)$ for a description of its construction and use. The use of this file is important because it accounts for changes in enterprise identifiers through mergers, and because it aggregates all plants to the enterprise level.
} 
number unique to a firm, and the LEAP serves to aggregate the possibly many account numbers per firm into a single longitudinally consistent identifier. For each individual (fathers and sons) who are part of our intergenerational data, and for each year from 1978 to 1996 we obtain unique firm identifiers on up to four employers. ${ }^{6}$ Very few individuals ever have more than four different employers in any given year. Using the individual's earnings from each employer we designate for a given year the firm accounting for the majority of total earnings as the "main" employer in that year, or sometimes over a five year horizon according to our analytical needs. ${ }^{7}$

On the basis of this information a son is defined to have the same employer as his father, during any given year from the age of 16 onward, if this employer at any point also employed the father in the past, as far back as the son's $15^{\text {th }}$ year. In order to create this variable we define a vector of time-varying same-employer indicators that are set equal to one in year $t$ if any of the son's employers in year $t$ were the same as any of the father's employers over the period 1978 to $t-1$ inclusive. This definition of the intergenerational transmission of employers involves up to four different employers per year for both sons and fathers. At age 33 it can be used to determine the life-time incidence of the intergenerational transmission of employers, showing whether the son at any point since the age of 16 had the same employer as his father.

\footnotetext{
${ }^{6}$ It is important to note that the LEAP is simply a catalogue of firms. In particular, we do not have information on all employees of all employers in the country, but rather are able to attach a firm identifier to the individuals - parents and children - who make up the intergenerational income data set. As such, for example, we are not able to determine the father's position in the income hierarchy of the firm.

${ }^{7}$ For example, the father's top four employers over the period the son was 15 to 19 years of age account for $96 \%$ of all earnings. The main employer represents $85.5 \%$ of total paternal earnings; the second employer accounts for a further $7.8 \%$; the third for $1.9 \%$ and the fourth for only $0.6 \%$. In the case of sons virtually all earnings are accounted for by the top four employers.
} 
We also define what we refer to as the "main" employer of both the father and the son to calculate an indicator of our second definition of the intergenerational transmission. The main employer of the father is defined to be the employer representing the majority of earnings during the years the son was 15 to 19 years age. For the sons, the main employer is considered to be the employer representing the majority of earnings at the age of 33. The intergenerational transmission of main employers is intended to indicate the extent to which parents make firm specific human capital investments in their children that imply an influence over employers defining the child's career.

The LEAP offers an accurate representation of the private sector but our analysis of the intergenerational transfer of employers is limited by the fact that it does not distinguish separate employers in the public sector. ${ }^{8}$ For anything finer than a two digit industry analysis this will overstate the degree to which employers or industries are passed across the generations. We therefore produce a set of results for two separate definitions of whether there is a match of employers between fathers and sons: one in which employment in the public service for both the father and son is considered to represent same firm employment, and one in which it is not. In fact, the findings do not vary significantly in kind, though there are differences in some of the descriptive results, with the former definition leading to a higher incidence of intergenerational transmission of employers. In what follows, we report results based upon the latter definition, observed

\footnotetext{
${ }^{8}$ This refers to the federal and provincial public services but not to municipal governments. The proportion of sons working in the public sector in any given year is between 6 and 8 percent at ages 18 and older, and between 0.8 and $3 \%$ at ages 15 to 17 .
} 
matches in the public sector are coded as not being matches. As a result the analysis offers conservative estimates of the degree of intergenerational job contacts. ${ }^{9}$

4. The incidence of intergenerational transmission of employers

By 33 years of age, just over $40 \%$ of sons are employed, or have been employed, at an employer that had at one time also employed their fathers. This result is presented in Figure 1, illustrating the proportion of sons who at any given age ever worked for an employer that at some point also employed their fathers. This is a cumulative variable that can only increase with time.

The actual rate of increase in the incidence of same firm employment slows significantly after about age 25 , and is relatively flat after age 27 . This could reflect a particular life cycle pattern. The intergenerational transmission of employers is highest in the early stages of the life cycle as individuals are working while at school, or making the transition from formal schooling to work. It increases from less than $10 \%$ to $30 \%$ during the teen years, and then rising more slowly to $40 \%$ during the $20 \mathrm{~s}$. This may reflect the possibility that parental referrals are most important in obtaining a first and possibly parttime or part-year job. However, in part it could also be the result of a mechanical effect arising from the fact that we only begin to observe the father and his employers when the child is 15 years of age. When the child is young we have a short history of employers to relate to his outcomes, which increases with each passing year. The fact that the change

\footnotetext{
${ }^{9}$ Excluding all public servants from the dataset would be inappropriate for at least two reasons. First, we want to preserve those cases when either the son or the father but not both are employed by the federal/provincial government. These observations are "true" zeros for the same firm indicator. Second, since we consider up to four employers in each year, it would be very difficult to establish a consistent exclusion rule across time for individuals changing employers.
} 
in the incidence of same firm employment flattens out by the late 20s suggest that this effect has worked itself out over the course of our observation period, but also that our final estimate must, once again, be consider an understatement.

The intergenerational transmission of main employer in adulthood is much lower than this "life-time" incidence. Just under six percent (5.6\%) of sons at the age of 33 have the same main employer their fathers had some 15 to 20 years earlier when the sons were teenagers.

Both of these statistics are relatively robust to our sample selection rules. As noted, the most important selection rule underlying the analytical sample concerns the requirement that fathers have positive earnings in each of five consecutive years during their sons' teen years. The selection rules also require that sons have positive earnings in each of three years during adulthood. These rules may lead to estimates of the intergenerational transmission of employers that are not representative of the population of young men, reflecting instead the subset of those from families with fathers having stable labour force attachment, and in the extreme being continuously employed. Accordingly we chose a much less stringent selection rule by requiring fathers and sons to have positive earnings only once over the same five and three year periods. This selection rule only requires fathers and sons to have had as few as one employer, and leads to a sample size of 109,158 rather than roughly 71,000 . This more inclusive sample leads to lower, but not appreciatively lower, estimates of the proportion of sons with the same employer as their father: $38.4 \%$ at age 33 have at some point since the age of 16 worked for an employer that also employed their father and $4.3 \%$ had as their main employer in adulthood the same main employer their father had 15 years earlier. 
At the same time there may also be a sense in which our estimates understate the truth. We have included all sons in the calculation regardless of whether or not the father's employer continues to exist. In some cases the employer goes bankrupt and the intergenerational transmission of employers is therefore not possible. However, more generally it is not just the death of a firm that will indicate the prospects of the son's employment, but also the firm's hiring policy. If the firm decides to shrink in size through attrition it may choose not to hire younger people at all. Incorporating these firms into the definition of "firm death" also helps to put a distinct upper bound to our estimates. To capture this, we define a 0-1 indicator if there are 30 to 33 year olds in 1996 employed by the firm. If there are none or if the firm no longer exists, then the variable "Firm Death" takes a value of 1 , otherwise zero. For the sake of simplicity we chose only the father's main firm when the son was 15 to 19 years of age to define this variable. Our calculations indicate that in $40.5 \%$ of cases the fathers' main employers were not in a position by the end of the period to hire the sons. By including these father-son pairs in the calculation it could be argued that we are understating the extent of the intergenerational transmission of employers. When we base our calculations conditional on the firm death variable not equaling one, the fraction of sons who have the same main employer as their father rises from $5.6 \%$ to $9.82 \%$. Conditional on the firm "surviving", the incidence of intergenerational transmission of employers is at the very most 1.75 times higher.

Finally, we note that the patterns in the intergenerational transmission of employers are related to paternal earnings. Higher paternal earnings are associated with a higher likelihood of intergenerational transmission of employers, and more specifically 
with a distinctly nonlinear pattern. Figure 2 illustrates the underlying proportions with same-firm employment across the percentiles of the parental earnings distribution.

Overall, the life-time incidence of same firm employment is $41 \%$ in these data, as given by the last observation in Figure 1. However, at percentiles below the $70^{\text {th }}$, the incidence of same firm employment is above $45 \%$ only once, hovering for the most part below $40 \%$ though higher at the $15^{\text {th }}$ and lower percentiles. At or above the $85^{\text {th }}$ percentile, it is above $45 \%$ eight times, and always above the average. The proportion of sons employed at some point with the same firm that at some point also employed their fathers rises sharply after the $95^{\text {th }}$ reaching $55 \%$ at the second highest percentile and almost $70 \%$ among the children of fathers in the top percentile. ${ }^{10}$

Similar patterns govern the narrower definition of same firm employment: main employer at age 33 matching the father's main employer when the son was 15 to 19 years of age. In this case the overall incidence of same firm employment is $5.6 \%$, and there is a clear positive tendency in this percentage across the father's earnings distribution starting at two to four percent at the bottom decile, and rising to six to eight percent at the ninth decile. Above the $95^{\text {th }}$ percentile this proportion also increases significantly, and particularly in the top percentile where $15 \%$ of sons have the same main employer their father had some 15 to 20 years earlier. ${ }^{11}$

\section{An assessment based on counterfactual populations}

\footnotetext{
${ }^{10}$ The standard error for these proportions is for the most part about $2 \%$, and about $1.7 \%$ at the very top of the distribution. As table 1 illustrates, the earnings cut-offs for the top 5\% and top $1 \%$ of fathers are just under $\$ 80,000$ and just over $\$ 125,000$ respectively.

${ }^{11}$ See Corak and Piraino (2009) for more details.
} 
The significance of these descriptive results depends upon the underlying reasons as to how employers are transmitted across generations. The labour market may be segmented, particularly between rural and urban areas, in a way that sons are likely to work for the same employer as their fathers by virtue of a lack of diversity in employment possibilities. In the extreme, imagine a labour market consisting of only single industry or single employer towns with no labour mobility between them. In this case, it is very likely that sons will at some point have worked with the same employer as their fathers. This may still have something to do with the mechanisms the theoretical literature focuses on: nepotism, contacts, and firm specific skills could in this context continue to be used to rank and allocate job applicants. But to some extent, it could also reflect the fact that even if sons were randomly allocated to firms, some considerable fraction would find a job with an employer who also employed their fathers.

Accordingly, we create a number of counterfactual populations in which sons are allocated to employers randomly within different geographic limits, different industries, and within the same earnings quartile. The latter is meant to proxy for skill differences between sons, our data not having a measure of education or other formal human capital investments. As such this is not entirely distinct from the influence of parental background, but we maintain this assumption for the sake of giving the counterfactual the maximum possible explanatory power. We derive the proportion that have the same employer as their father for as detailed cells the sample size can reasonably support. The idea is that these statistics will help bound the degree to which the intergenerational transmission of employers reflects something more than just a lack of diversity in employment possibilities. 
More specifically, we draw five hundred replications of a sample based upon random allocation of firms across sons in a way that preserves the same number of sons in each firm, and the overall number of individuals and firms as in the actual data. The assignment is done without replication, so that the final distribution reflects the same overall employment levels by firm as the actual sample of sons. To make the exercise manageable we focus solely on the main employer in adulthood. The results are reported in Table 2 using all firms, and only the firms not dying in the sense defined previously. The table reports the mean incidence and its standard deviation across the 500 replications for each of eleven different scenarios.

The first counterfactual, referred to as "Full random assignment," offers an estimate of the incidence of same main firm employment across generations if sons were randomly assigned to any enterprise in the country employing their generation. The second row refers to a random allocation across all firms within the same two-digit industry, while the third row reports similar results within the same earnings quartile, and the fourth within a combination of industry and earnings. In no cases would the resulting distribution of sons across employers imply much more than about one-third of one percent of sons working with the same employer as their father.

The remaining rows of the table add a geographic dimension. The results in row 5 refer to a reallocation of sons in the same first digit of the postal code, which divide the country into 18 distinct regions. ${ }^{12}$ A rural versus urban dimension is offered in row 6 , and

\footnotetext{
${ }^{12}$ The first digit of the postal code is a letter, which uniquely identifies a province with the exception of the larger provinces. Ontario is divided into five sub-regions, and Quebec into three. As such there are a total of 18 indicators for province/region, which in addition to the ten provinces includes two indicators for the three northern territories. The second digit of the postal code is a number that can be used to identify if the
} 
the finest regional break down, using the first two digits of the postal code and hence 135 distinct regions, is offered in row 7. A random allocation of sons across firms within these different geographic boundaries also leads to a maximum of one-third of one percent being employed at the same employer as their father, substantially below the 5.6 percent figure observed in the data.

In the last four rows of Table 2 the reference is to cross-classifications of region, industry, and earnings. These are the finest cells we are able to define with the sample size available to us, and the highest estimate of the intergenerational transmission of employers is $1.5 \%$ when the randomization occurs across two-digit industries within the smallest geographic area (row 10). The patterns are the same in the second set of results offered for the firms not dying, with highest estimate of the proportion of same employer across the generations being less than one-third of the figure actually observed in the data.

In other words, our simulations show that even if we were to randomly deploy the sons in our sample to employers in the same industry, operating in the same geographical region, and requiring a similar set of skills — as roughly proxied by the regional withinindustry earnings quartile - the resulting intergenerational transmission of employers would still be significantly lower than actually observed. There is something more than a preference for a specific region, industry sector, and wage range that leads sons to be employed in exactly the same firm that once employed their fathers.

\section{Linear probability models of the role of family background}

postal code refers to an urban or rural area. See www.canadapost.ca/personal/tools/pg/manual/PGaddresse.asp for details. 
These results suggest that other aspects of family background may influence the inheritance of employers, and we explore these correlates in more detail using a series of linear probability models. The dependent variables are $0-1$ indicators of the two measures, reflecting the overall averages of $41 \%$ and $5.6 \%$. We consider two sets of variables: the individual characteristics of the father; the characteristics of the firm. The definition of these variables and associated descriptive statistics are presented in Table 3. The natural logarithm of father's earnings and earnings squared are included to capture the patterns illustrated in Figures 2, while the father's age and age squared are used to control for possible life-cycle differences. The number of employers the father had over a ten year period is intended to indicate both the extent of the network the son may draw upon, and also the father's reputation. ${ }^{13}$ It also refers to the scope for the transmission of firm-specific attributes: the greater the number of previous employers, the less likely the father has any firm specific capital to pass on to his son. As such we expect this variable to have a positive influence in the model of ever same employer-reflecting the role of networks - but a negative influence in the model of same main employer. ${ }^{14}$ On

\footnotetext{
${ }^{13}$ If the father has worked with many firms, then this may imply a higher likelihood the son will be employed at a firm that also employed the father: there is simply a wider set of contacts upon which the son may draw. But this presupposes that the father is seen by the employer as offering reliable information about a high-quality match. For example, Montgomery (1991) offers a formal model of a job referral process where the father's contacts raise the son's job offer arrival rate if the father has a positive reputation, and is considered by the employer to be a reliable source of information about the unobserved characteristics of the son. In Montgomery's model firms do not make job offers to those referred by lowability employees. Further, low-ability workers are of lower productivity and will have shorter job tenures. This implies that fathers who are low-ability will experience more job turnover, and as such the number of employers we observe the father to have over an extended period may reflect a poor reputation from which the son cannot benefit. Consequently, we can expect a non-linear relationship between the number of paternal employers and the likelihood that they will be transmitted inter-generationally: first increasing as the number of parental employers increases, and then decreasing as the pool of fathers with a higher number of employers becomes increasingly dominated with lower-quality workers.

${ }^{14}$ Magruder (2010) uses a roughly similar approach to distinguish these two models. His analysis is looks at the intergenerational correlation of industries, and uses fathers how have been industry-switchers to examine the role of their past industries on the industry of employment for the son.
} 
average, fathers have 2.8 employers over a ten year period, but the standard deviation at 2.9 is actually a bit higher than the mean.

The model also includes a series of 0-1 indicator variables for the presence of non-zero self-employment income over a five year period, be it from farming, fishing, professional, or from other more common sources of self-employment associated with unincorporated businesses. These variables offer an indication of possibly a heightened degree of control over the firm's hiring practices. It should be noted that for the time being our analysis is based upon paternal earnings, not total income. The value of selfemployment income could be positive or negative, our concern not being with the amount but with the possibility that the father may have direct control over hiring practices.

About $11 \%$ of fathers are in this situation. Strictly speaking, however, we cannot identify if this income is from the same firm generating the father's earnings. This indicator of the presence of self-employment income is also interacted with the natural logarithm of father's earnings and earnings squared to permit the influence to vary across the earnings distribution.

These variables_-father's earnings, number of employers, and self-employment income - are of most interest to us, reflecting the capacity to promote the labour market outcomes of the son through job search, specific human capital investments, or nepotism. $^{15}$

\footnotetext{
${ }^{15}$ In order to hold constant the diversity of the employment prospects of the son we include a series of region indicators of where the father lived when the son was still living with him. Following the analysis in the previous section these indicators are derived from the first two digits of the postal code, and offer information on rural and urban areas as well as provincial and sub-provincial regions. Almost threequarters of the observations are to be found in urban areas. We also use the indicator of firm death. The firm size at the onset of the period is also controlled for using a series of indicator variables. This refers to the total number of fathers in our data employed by the firms, and not therefore to the total number of employees. Oreopoulos, Page, and Stevens (2008) also use this variable, and note that it represents not
} 
The results for a series of specifications are presented in Tables 4 and 5 for the two definitions of the dependent variable. A quadratic relationship between paternal earnings and the chances of same-firm employment is robust to the specification, and the particular parameter values suggest the relationship is parabolic being highest for sons from highest earning fathers. The relationship between the number of employers the father had and chances of same-firm employment is an inverted U-shape in Table 4, suggesting that increases in the number of employers the father had to a maximum of between 7 and 8 over a ten year period increases the likelihood the son will be employed at one of them. The pattern is in fact the opposite when the focus is on the same main firm dependent variable in Table 5, with more paternal employers lowering the likelihood that the child will be employed in the same main firm of the father. Both of these patterns are in accord with our priors, a larger number of employers indicating in the former case a wider set of contacts, but in the latter that the father may not have had a strong foothold in any particular firm and hence less likely to pass on any firm-specific capital to the son.

Of the four indicators of the type of income, only the indicator for self employment income is consistently statistically significant, having the expected positive sign. The last specification in Table 4 indicates that this influence plays somewhat through the amount of the father's earnings. These estimates imply that at the sample mean of paternal earnings, having a father with some self-employment income raises the

quite one-tenth of actual firm size as indicated by the full LEAP database. About $50 \%$ of fathers are in the smallest category, with the next highest proportions in the larger categories: $14 \%$ and $12 \%$ in firms of more than 100 and more than 500 of these workers. Finally, we include a number of characteristics of the two digit industry to which the father's main firm is classified: the employment growth over the period, the average years of education of all employees, an interaction of this latter variable with the father's income, and indicator variables for the two-digit SIC. These capture the overall chances of employment, the educational requirements - the ability to meet them potentially varying with the father's earnings — and any industry specific differences in hiring practices such as the rate of unionization. 
probability of ever having worked in the same firm by $5.9 \%$, slightly higher than the $4.8 \%$ estimate in the previous column based upon no interaction effects. There is no such impact when the focus is on the main employer, the interactions not being statistically significant in column (6) of Table 5. Other forms of self-employment associated with agriculture and fishing are not statistically significant, nor is the indicator for the presence of professional income. ${ }^{16}$

While these results include controls for detailed region and industry indicators, we check their robustness by offering estimates separately for urban and rural region using the specification in column (6) of these tables. Tables 6 and 7 present selected findings across geographic regions for our two definitions. The tables report the estimated coefficients for the variables we are most interested—father's earnings, father's number of employers, and the presence of self-employment income - and indicate that they do not change across the two geographic areas, with one possible exception. In Table 6 the major difference between the two subsamples is the finding that the number of employers the father had is stronger in magnitude in the rural sample. The higher rural coefficients may be interpreted as indicating that any given number of employers the father has represents a greater proportion of the total possible employers with which the son may be employed. But this does not seem to be the case in Table 7, where the focus is on the career employer as opposed to any employer.

We also recognize that the estimates offered in Tables 4 and 5 are based entirely upon father's earnings, though indicators for the presence of self-employment and other

\footnotetext{
${ }^{16}$ The firm death variable is estimated to be negative, as is the indicator of urban residence. Finally, the use of the industry dummy variables seems to clarify the role of firm size, their inclusion indicating that sons are most likely to be hired in smaller than in larger firms.
} 
types of income are included. As such earnings may not accurately represent the total financial resources available to the father. The last column of Tables 6 and 7 offers estimates based upon the father's total market income, which includes self-employment income, as the regressor. This increases the magnitude and the statistical significance of the self-employment indicator and the associated interactions, particularly in Table 7 where the focus is on the main same employer. The earnings-based analysis did not reveal a statistically significant impact of having a father reporting self-employment income on the chances that main firms were transmitted across generations. These results suggest that this is in fact the case for both definitions of generational employer transmission, but it should be noted that it remains much stronger in magnitude when determining the likelihood of the son getting a job as opposed to getting a career job.

In summary, the most notable results in these tables are the robust positive relationship with respect to father's self-employment income, the nonlinear positive relationship between parental earnings and the probability of same firm employment, and the contrasting patterns across the two tables with respect to the father's number of employers.

7. The relationship between employers and earnings across the generations The transmission of employers across the generations has implications for the generational transmission of earnings. The empirical analysis of intergenerational earnings mobility makes extensive use of a linear regression to the mean model: $\ln Y_{t}=\alpha$ $+\beta \ln Y_{t-1}+\varepsilon_{t}$, where $Y$ is a measure of permanent income, $t$ indexes generations, and 
where $\beta$, the intergenerational earnings elasticity, is the parameter of interest. ${ }^{17}$ There is a consensus on the value of $\beta$ for Canada. Corak and Heisz (1999) estimate it to be about 0.2 with the same data that is the basis of our paper, while Fortin and Lefebvre (1998) use survey data and instrumental variables methods and obtain a similar value.

Tables 8 and 9 present least squares estimates of the intergenerational elasticity, for the two alternative definitions of same firm employment using various versions of the following general specification:

$$
\begin{aligned}
\ln Y_{i, t}= & \alpha+\beta \ln Y_{i, t-1}+\beta_{1} \ln Y_{i, t-1} \times \text { SameFirm }_{i}+ \\
& \gamma_{1} \text { SameFirm }_{i}+\gamma_{2} \text { SameIndustry }_{i}+\gamma_{3} \text { SameRegion }_{i}+\varepsilon_{i, t}
\end{aligned}
$$

The main concern is with the interaction term $\beta_{1}$, which measures the influence of the intergenerational transmission of employers on the intergenerational earnings elasticity. We define the same industry and same region variables to be indicators of employment in the same two-digit industry, and residence in the same narrowly defined region (the first two digits of the postal code being the same).

The results suggest that the overall average elasticity of earnings is $0.25 .^{18}$ The presence of the intergenerational transmission of employers has a slight tendency to increase the overall average elasticity, as indicated by the change in the estimate between

\footnotetext{
${ }^{17}$ The theoretical motivation for this equation is Becker and Tomes $(1986,1979)$ and Loury $(1981)$, but there is an extensive empirical literature informed in a significant degree by Solon $(1992,1989)$ and Zimmerman (1992) who highlight the challenges measurement errors and life cycle biases pose in correctly estimating the elasticity. Surveys of this empirical research include Björklund and Jäntti (2008), Corak (2006), and Solon (2002, 1999), with Böhlmark and Lindquist (2006), Grawe (2006), and Haider and Solon (2006) offering the most recent methodological developments.

${ }^{18}$ This is slightly higher than those reported in Corak and Heisz (1999) because we are using only the oldest cohort of the data available to them. When our estimations are based on all available cohorts the resulting estimate is 0.226 .
} 
columns (1) and columns (2) to (4) of these tables. ${ }^{19}$ When the focus is on the son ever having been employed at the same firm as the father the overall elasticity falls from 0.25 to about 0.20 for those not having the same employer, and rises to about 0.3 for those who do have the same employer. But this tendency is less notable in the case of same main employer being the same. Table 9 illustrates that the overall elasticity of 0.25 falls at most to 0.22 when controls for same industry and same region are included, and even less otherwise. While the degree of generational mobility is significantly lower for sons with the same main firm as fathers (the elasticity rising to about 0.4 ), this does not significantly change the overall measure of mobility.

The notable feature in Corak and Heisz (1999), however, is that the large sample size permits estimation of non-linear patterns in the intergenerational elasticity. They find that the intergenerational elasticity rises over the lower half of the father's earnings distribution peaking at about 0.3 , falls over the upper half, and then rises sharply to 0.4 and even higher at the very top of the distribution. ${ }^{20}$ As such the linear model is not an accurate representation of the actual patterns in the elasticity across the father's earnings distribution.

The influence of the inheritance of employers is more important at some points in the father's earnings distribution than others, and contributes to these non-linear patterns.

\footnotetext{
${ }^{19}$ The influence of the intergenerational transmission of employers on the degree of generational earnings mobility in this regression to the mean model is examined in detail by Corak and Piraino (2009), who use estimates of this sort as a starting point, but argue that the appropriate estimation strategy is a switching regression with sample separation unknown or known imperfectly.

${ }^{20}$ Solon (1992) was not able to address variation in the intergenerational elasticity across the father's earnings distribution conclusively with PSID data, but Bratsberg et al. (2007) document non-linear patterns for other countries, some of which have a similar average elasticity as Canada. The reasons for these patterns are the subject of discussion in the literature, with the possibility of credit constraints in the manner of Becker and Tomes (1986) representing the starting point for many analyses, and indeed for some of the conjectures in Corak and Heisz (1999). Grawe (2004) brings this interpretation into question, and Han and Mulligan (2001) explore the issue in detail.
} 
Figures 3 and 4 show these distinct non-linear patterns according to whether the son worked at the same employer as his father or not. ${ }^{21}$ The intergenerational earnings elasticity is much higher throughout the father's earnings distribution for those sons ever having the same employer as their fathers. For example, in Figure 3 the intergenerational elasticity for this group is for the most part above 0.2 , but for those not experiencing the intergenerational transmission of an employer it just exceeds this value at its maximum. Relatively speaking the elasticity is also much higher at the upper tail given that it tends to fall off throughout the upper half of the earnings distribution for sons not employed at the same firm as their fathers. This suggests that part of the preservation of earnings across the generations for sons of the top-earning fathers has to do with the intergenerational transmission of employers. In fact, the negative estimate when fathers have earnings more than one standard deviation above the mean for those not having the same employer as their fathers indicates an intergenerational reversal of earnings.

All of this is particularly so in reference to the more narrow measure of same firm employment: when the son has the same main employer as an adult that his father had 15 or so years earlier the intergenerational earnings elasticity ranges from 0.5 to 0.8 when earnings are more than two standard deviations from the mean. In addition, for the large part of the distribution in the lower half of the earnings distribution the value is also notably high and relatively constant at about 0.5 . Most clearly, however, if there is a sharp spike in the intergenerational elasticity at the top of the earnings distribution for the

\footnotetext{
${ }^{21}$ The results are based upon a nearest-neighbourhood estimator with locally-weighted least squares regressions, as described in Loader (1999) and as implemented in S-Plus. The weighting function is the tricubic, a cubic functional form is used for the regression, and the span is set at 0.7 . These are the same specifications as Corak and Heisz (1999).
} 
population as a whole, as observed in Corak and Heisz (1999), this exclusively reflects the elasticity for those working as adults for the same main employer as their father.

\section{Conclusion}

We document the intergenerational transmission of employers between fathers and sons with a large Canadian based administrative data set by deriving two complementary indicators. The first is related to the job search process and the role of parental networks, and speaks to the empirical findings in the job search literature that most jobs are found through families and friends. The second is related to the specific investments that parents may make in the human capital of their children in a way that increases productivity in particular firms. Both of these indicators will also be influenced by the capacity of parents to directly influence the recruitment process in particular firms, which we expect to be more important among higher earning parents.

Our analysis does not exclude any of these models of the intergenerational transmission of employers. Rather we illustrate that each has a bearing on observed patterns, with each being more relevant at different points in the series of transitions young people make in obtaining their career jobs. We find that by the age of 33 approximately 4 in 10 men have worked at some point with an employer who had also at some point employed their father. Much of this intergenerational transmission of employers occurs during the teen years, but as a lower bound about $6 \%$ (and as an upper bound $9 \%$ ) of 33 year olds have as their main employer the same employer their fathers worked for some 15 to 20 years earlier. These percentages are higher than would be expected by a random allocation of sons to firms in specific industrial, regional, and sub- 
regional labour markets, and reflect particular characteristics of their family background. The intergenerational transmission of employers is much more likely at the top of the earnings distribution. Close to $70 \%$ of sons of top percentile fathers had at some point the same employer as their fathers, and for $15 \%$ their main employer at the age of 33 was the same employer their father worked for during their teen years.

Our results from a series of linear probability models are consistent with a set of hypotheses we draw from literature. First, the generational transmission of employers is higher when fathers have self-employment income, and higher for fathers with higher earnings and incomes. In particular, the probability that sons will be employed by the same employer as their father is distinctly non-linear, being much higher for the highest earning fathers. Second, self-employment also significantly tightens the relationship between parental earnings and intergenerational transmission of employers. These findings do not reject the hypothesis that the generational transmission of employers reflects some direct parental influence over the hiring process. Finally, the more employers the father has had, the more likely the son will be employed at one of them at some point in his life. But the more employers the father has had, that is the less likely he has any firm specific capital to pass on, the less likely the son will be employed at one of them as a career in adulthood. As such our findings are also in line with the predictions of both the job search model, and a model of firm-specific human capital: the first reflecting in large measure the jobs young people find during their teen years and in making the transition from school to work, the second their employers in adulthood.

These patterns have consequences for the intergenerational transmission of earnings. We find that while the intergenerational transmission of employers slightly 
raises the overall average intergenerational elasticity of earnings, it has a larger bearing on understanding non-linear patterns in this elasticity across the father's earnings distribution. In particular, the elevated elasticities observed in the middle of the earnings distribution as well as in the upper tail of these Canadian data reflect the patterns of those who also inherit an employer from their father.

The literature on the degree of generational earnings mobility is oftentimes linked to the growing research on early childhood development, the formation of values and preferences, and their impact on readiness to learn and pro-social behaviour that are all important antecedents to educational attainment and ultimately labour market success. Our research suggests that it is also important to understand the nature of labour markets and the way in which young adults interface with them during the transition to adulthood, and ultimately in final career choices. Parents may also be in a position to influence this process by offering contacts and knowledge of employment with particular employers, and in the extreme exercising direct control. This may be an important complement to the non-monetary investments early in life. The capacity of parents to play a role in a child's transition to the labour market varies according to their place in the earnings distribution, and this may also be a part of the explanation for the degree to which children may have similar earnings as their parents, a possibility that future research with data from other countries should recognize. 


\section{References}

Bennedsen, Morton, Kasper Meisner Nielsen, Francisco Pérez-González, and Daniel Wolfenzon (2007). "Inside the Family Firm: The Role of Families in Succession Decisions and Performance." Quarterly Journal of Economics. Vol. 122, pp. 64791.

Björklund, Anders and Markus Jäntti (2009). "Intergenerational income mobility and the role of family background.” In Wiemer Salverda, Brian Nolan, and Tim Smeeding (editors). Handbook of Economic Inequality. Oxford: Oxford University Press.

Blanden, Jo (2005). "Love and Money: Intergenerational Mobility and Marital Matching in Canada." Ottawa: Statistics Canada Research Paper No. 272.

Bratsberg, Bernt, Knut Roed, Oddbjorn Raaum, Robin Naylor, Markus Jantti, Tor Eriksson, and Eva Osterbacka (2007). "Nonlinearities in Intergenerational Earnings Mobility: Consequences for Cross-country Comparisons." Economic Journal. Vol. 117, pages C72-C92.

Corak, Miles (2006). "Do poor children become poor adults? Lessons from a cross country comparison of generational earnings mobility.” In John Creedy and Guyonne Kalb (editors). Research on Economic Inequality, Vol. 13. Amsterdam: Elsevier.

Corak, Miles (2001). "Death and Divorce: The Long-Term Consequences of Parental Loss on Adolescents.” Journal of Labor Economics. Vol. 19, pp. 682-715. Corak, Miles, Björn Gustafsson, and Torun Österberg (2004). "Intergenerational Influences on the Receipt of Unemployment Insurance in Canada and Sweden.” In 
Miles Corak, editor. Generational Income Mobility in North America and Europe. Cambridge: Cambridge University Press.

Corak, Miles and Andrew Heisz (1999). "The Intergenerational Earnings and Income Mobility of Canadian Men: Evidence from Longitudinal Income Tax Data.” Journal of Human Resources. Vol. 34, pp. 504-33.

Corak, Miles and Patrizio Piraino (2010). "Intergenerational Earnings Mobility and the Inheritance of Employers." Unpublished.

Dunn, Thomas and Douglas Holtz-Eakin (2000). "Financial Capital, Human Capital and the Transition to Self-Employment: Evidence from Intergenerational Links.” Journal of Labor Economics. Vol. 18, pp. 282-305.

Fortin, Nicole and Sophie Lefebvre (1998). "Intergenerational Income Mobility in Canada." In Miles Corak (editor). Labour Markets, Social Institutions and the Future of Canada's Children. Ottawa: Statistics Canada.

Granovetter, Mark S. (1995). Getting a Job: A Study of Contacts and Careers. Second Edition. Chicago: University of Chicago Press.

Grawe, Nathan D. (2006). "The Extent of Lifecycle Bias in Estimates of Intergenerational Earnings Persistence.” Labour Economics. Vol. 13, pp. 551-570.

Grawe, Nathan D. (2004). "Reconsidering the Use of Nonlinearities in Intergenerational Earnings Mobility as a Test for Credit Constraints." Journal of Human Resources. Vol. 39, pp. 813-827.

Grenon, Lee (1999). “Obtaining a job.” Perspectives on Labour and Income. Ottawa: Statistics Canada, catalogue number 75-001. 
Haider, Steven J. and Gary Solon (2006). "Life-Cycle Variation in the Association between Current and Lifetime Earnings." American Economic Review. Vol. 96, pp. $1308-20$.

Harris, Shelly and Daniela Lucaciu (1994). “An overview of the T1FF Creation.” LAD Reports. Reference Number 94-24-01 v1.2. Ottawa: Statistics Canada, Small Areas and Administrative Data Division.

Holzer, Harry J. (1988). “Search Method Use by Unemployed Youth.” Journal of Labor Economics. Vol. 6, pp. 1-20.

Ionnides, Yannis M. and Linda Datcher Loury (2004). "Job Information Networks, Neighborhood Effects, and Inequality.” Journal of Economic Literature. Vol. 42, pp. 1056-93.

Kimhi, A. and N. Nachlieli (2001). "Intergenerational succession on Israeli family farms." Journal of Agricultural Economics. Vol. 52, pp. $42-58$.

Kramarz, Francis and Oskar Nordström Skans (2007). "With a little help from my ... Parents? Family Networks and Youth Labor Market Entry." CREST Working Paper.

Jonsson, Jon O., David B. Grusky, Matthew Di Carlo, Reinhard Pollak, and Mary C. Brinton (2009). "Microclass Mobility: Social Reproduction in Four Countries." American Journal of Sociology. Vol. 114, pp. 977-1036.

Laband, D.N. and B.F. Lentz (1983). "Occupational inheritance in agriculture.” American Journal of Agricultural Economics. Vol. 65, pp. 311-314.

Laband, D. N. and B. F. Lentz (1992). "Self-recruitment in the legal profession." Journal of Labor Economics. Vol. 10, pp. 182-201. 
Lentz, B. and D. N. Laband (1990). "Entrepreneurial success and occupational inheritance among proprietors.” Canadian Journal of Economics. Vol. 23 pp. 56379.

Lentz, B. and D. N. Laband (1989). "Why so many children of doctors become doctors: nepotism vs. human capital transfers.” Journal of Human Resources. Vol. 24, pp. 396-413.

Loader, Clive (1999). Local Regression and Likelihood. New York: Springer-Verlag. Loury, Glenn C. (1981). "Generational Transfers and the Distribution of Earnings.” Econometrica. Vol. 49, pp.843-67.

Loury, Linda Datcher (2006). "Some contacts are more equal than others: Informal networks, job tenure, and wages.” Journal of Labor Economics. Vol. 24, pp. 299318.

Magruder, Jeremy R. (2010). “Intergenerational Networks, Unemployment, and Persistent Inequality in South Africa.” American Economic Journal: Applied Economics. Vol. 2, pp. 62-85.

Montgomery, James D. (1991). "Social Networks and Labor-Market Outcomes: Toward an Economic Analysis." American Economic Review. Vol. 81, pp. 1408-1418.

McNally, Sandra (2003). “Aspects of Structural Change on European Farms: an empirical analysis." PhD Thesis. University College London.

Morgan, Stephen, Gary Fields and David B. Grusky, editors (2006). Mobility and Inequality: Frontiers of Research from Sociology and Economics. Stanford: Stanford University Press. 
Oreopoulos, Philip (2003). “The Long-Run Consequences of Growing Up in a Poor Neighborhood." Quarterly Journal of Economics. Vol. 118, pp. 1533-75.

Oreopoulos, Philip, Marianne Page, and Ann Huff Stevens (2008). “The Intergenerational Effects of Worker Displacement.” Journal of Labor Economics. Vol. 26, pp.455-84. Pérez-González, Francisco (2006). "Inherited Control and Firm Performance.” American Economic Review. Vol. 96, pp. 1559-88.

Polachek, S. W. (1986). "Roots of success: why children follow in their parents' career footsteps.” Book review. Journal of Economic Literature. Vol. 24, pp. 1839-41.

Rosenzweig, M. R. and K. I. Wolpin (1985). "Specific experience, household structure and intergenerational transfers: farm family land and labor arrangements in developing countries." Quarterly Journal of Economics. Vol. 100, pp. 961-87.

Roemer, John E. (2004). "Equal Opportunity and Intergenerational Mobility: Going Beyond Intergenerational Income Transition Matrices.” In Miles Corak (editor). Generational Income Mobility in North America and Europe. Cambridge: Cambridge University Press.

Solon, Gary (2002). "Cross-Country Differences in Intergenerational Earnings Mobility." Journal of Economic Perspectives. Vol. 16, pp. 59-66.

Solon, Gary (1999). “Intergenerational Mobility in the Labor Market.” In Orley C. Ashenfelter and David Card (editors). Handbook of Labor Economics, Volume $3 \mathrm{~A}$. Amsterdam: Elsevier Science.

Solon, Gary (1989). "Biases in the Estimation of Intergenerational Earnings Correlations." Review of Economics and Statistics. Vol. 71, pp. 172-74. 
Statistics Canada (1992). Worker Turnover in the Canadian Economy: Separations and Hirings, 1978-1989. Ottawa: Statistics Canada, Catalogue Number 71-539. Statistics Canada (1988). Developing a Longitudinal Database on Businesses in the Canadian Economy. Ottawa: Statistics Canada, Catalogue Number 18-501. 


\section{Table 1}

\section{Descriptive statistics for fathers and sons linked intergenerationally}

\begin{tabular}{|c|c|c|c|c|c|c|}
\hline \multirow{2}{*}{$\begin{array}{l}\text { Number } \\
\text { of } \\
\text { observed } \\
\text { father-son } \\
\text { pairs }\end{array}$} & \multicolumn{2}{|c|}{ Average Age } & \multicolumn{2}{|c|}{ Average Earnings } & \multicolumn{2}{|c|}{$\begin{array}{c}\text { Number of } \\
\text { unique employers }\end{array}$} \\
\hline & $\begin{array}{l}\text { Fathers } \\
(1980)\end{array}$ & $\begin{array}{l}\text { Sons } \\
(1996)\end{array}$ & Fathers & Sons & Fathers & Sons \\
\hline \multirow[t]{4}{*}{71,215} & $\begin{array}{l}47.35 \\
(6.14)\end{array}$ & $\begin{array}{c}33 \\
(0.00)\end{array}$ & $\begin{array}{c}43,524 \\
(27,085)\end{array}$ & $\begin{array}{c}36,129 \\
(22,953)\end{array}$ & 23,991 & 31,729 \\
\hline & \multicolumn{6}{|c|}{ Fathers' earnings percentiles } \\
\hline & $5^{\text {th }}$ & $25^{\text {th }}$ & $50^{\text {th }}$ & $75^{\text {th }}$ & $95^{\text {th }}$ & $99^{\text {th }}$ \\
\hline & 15,231 & 29,794 & 39,671 & 51,973 & 79,910 & 126,195 \\
\hline
\end{tabular}

Note: The sample refers to father and son pairs in which the sons are born in 1963, and who are hence 33 years of age in 1996.

Fathers' earnings refer to the average over the five year average the son was 15 to 19 years of age, expressed in 1992 constant dollars. Sons' earnings are averaged over the ages of 30 to 33. The number of unique employers refers only to the main employer, the employer that paid the largest proportion of total earnings during the above periods. Figures in parentheses are standard deviations. 
Table 2

Incidence of the intergenerational transmission of same main firm for different simulated populations in which sons are randomly assigned to employers

\begin{tabular}{|c|c|c|c|c|}
\hline & \multicolumn{2}{|c|}{ All Firms } & \multicolumn{2}{|c|}{ Firms not dying } \\
\hline & Per cent & $\begin{array}{l}\text { Standard } \\
\text { deviation }\end{array}$ & Per cent & $\begin{array}{l}\text { Standard } \\
\text { deviation }\end{array}$ \\
\hline Country wide incidence of same firm employment & 5.586 & & 9.394 & \\
\hline 1. Full random assignment & 0.041 & $(0.008)$ & 0.081 & $(0.013)$ \\
\hline 2. Within two-digit industries & 0.287 & $(0.019)$ & 0.544 & $(0.035)$ \\
\hline 3. Within earnings quartile & 0.047 & $(0.008)$ & 0.090 & $(0.015)$ \\
\hline 4. Within two-digit industries and earnings quartile & 0.368 & $(0.020)$ & 0.685 & $(0.036)$ \\
\hline 5. Within $1^{\text {st }}$ digit postal code & 0.150 & $(0.016)$ & 0.291 & $(0.027)$ \\
\hline 6. Within urban/rural areas & 0.156 & $(0.015)$ & 0.306 & $(0.025)$ \\
\hline 7. Within $2^{\text {nd }}$ digit postal code & 0.341 & $(0.019)$ & 0.646 & $(0.035)$ \\
\hline 8. Within $1^{\text {st }}$ digit postal code and industry & 0.884 & $(0.028)$ & 1.620 & $(0.045)$ \\
\hline $\begin{array}{l}\text { 9. Within } 1^{\text {st }} \text { digit postal code, industry, earnings } \\
\text { quartile }\end{array}$ & 1.040 & $(0.027)$ & 1.887 & $(0.047)$ \\
\hline 10. Within $2^{\text {nd }}$ digit postal code and industry & 1.455 & $(0.026)$ & 2.738 & $(0.040)$ \\
\hline 11. Within $2^{\text {nd }}$ digit postal code and earnings quartile & 0.375 & $(0.020)$ & 0.716 & $(0.036)$ \\
\hline
\end{tabular}

Note: See definitions in the text. The first row in each panel represents the actual proportion of sons observed to have as their main employer in adulthood being the same as their fathers. All other figures are the mean proportions of simulation results based upon 500 replications of a random allocation of employers across sons. Standard deviations are reported in parentheses. 
Table 3

Descriptive information on variables used in modeling the incidence of intergenerational transmission of employers for a cohort of 33 year old men

\begin{tabular}{|c|c|c|c|}
\hline & Variable definition and description & Mean & $\begin{array}{l}\text { Standard } \\
\text { Deviation }\end{array}$ \\
\hline \multicolumn{4}{|l|}{ Dependent Variable } \\
\hline Ever Same Firm & $\begin{array}{l}0-1 \text { indicator of whether the son had by the } \\
\text { age of } 33 \text { employment in any given year } \\
\text { since the age of } 16 \text { with a firm that } \\
\text { employed his father in any previous year }\end{array}$ & 0.410 & \\
\hline Same Main Firm & $\begin{array}{l}0-1 \text { indicator of whether the employer } \\
\text { accounting for the majority of the son's } \\
\text { earnings between at the age of } 33 \text { is the } \\
\text { same as the employer accounting for the } \\
\text { majority of the father's earnings when the } \\
\text { son was } 15 \text { to } 19 \text { years of age }\end{array}$ & 0.056 & \\
\hline \multicolumn{4}{|l|}{ Father's Characteristics } \\
\hline $\begin{array}{l}\ln \text { earnings } \\
\ln \text { earnings }\end{array}$ & $\begin{array}{l}\text { Natural logarithm of } 5 \text { year average of } \\
\text { father's earnings when the son was } 15 \text { to } 19 \\
\text { years of age, and its value squared }\end{array}$ & 10.6 & 0.514 \\
\hline $\begin{array}{l}\text { Number of employers } \\
\text { Number of employers }\end{array}$ & $\begin{array}{l}\text { The number of different employers the } \\
\text { father had over the ten year period } 1978 \text { to } \\
\text { 1988, and its value squared }\end{array}$ & 2.83 & 2.87 \\
\hline Farming income & $\begin{array}{l}\text { Presence of non zero income from farming } \\
\text { at least once over a five year period }\end{array}$ & 0.0573 & \\
\hline Fishing income & $\begin{array}{l}\text { Presence of non zero income from fishing at } \\
\text { least once over a five year period }\end{array}$ & 0.00437 & \\
\hline Professional income & $\begin{array}{l}\text { Presence of non zero professional income at } \\
\text { least once over a five year period }\end{array}$ & 0.0156 & \\
\hline Self employment income & $\begin{array}{l}\text { Presence of non zero income from other } \\
\text { sources of self-employment over a five year } \\
\text { period }\end{array}$ & 0.112 & \\
\hline $\begin{array}{l}\text { Age } \\
\text { Age }^{2}\end{array}$ & $\begin{array}{l}\text { Average age during the years the son was } 15 \\
\text { to } 19 \text { years old, and its value squared }\end{array}$ & 47.3 & 6.13 \\
\hline
\end{tabular}

Firm and industry characteristics

Province / Region

A series of 18 indicator variables of the region of father's residence derived from the first digit of the postal code. These are provinces with the exception of Ontario which is divided into 5 sub-provincial regions and Quebec which is divided into three. Metropolitan Toronto serves as the omitted category in the estimations.

A 0-1 indicator of whether the father lived in

Urban an urban area as indicated by a non-zero 0.728 value for the second digit of the postal code 
Firm Death

Firm Size 1 to 10

Firm Size 11 to 20

Firm Size 21 to 50

Firm Size 51 to 100

Firm Size 101 to 500

Firm Size 501 and more

Industry employment growth

Average years of schooling by two digit industry

Two digit industry indicators
An indicator of whether the father's main employer when the son was 15 to 19 employed at least one person 30 to 33 years of age in 1996

Indicator variables of the total number of 0.497 employees of the father's main employer during the years the son was 15 to 19 years 0.071 of age. The largest category serving as the 0.103

0.070 reference in the estimation.

0.142

0.117

Difference between the natural logarithms of the total employment in the 2-digit industry of the fathers main employer in the 1981 and 1996 Census of population

Average years of schooling of all employees in the 2 digit SIC 1980 industry of the 1.25 fathers main employer in the 1996 Census of population

A series of 75 indicator variables for the 2digit SIC 1980 industry of the father's main firm when the son was 15 to 19 years old

Interactions

ln earnings $\times$ years industry average schooling

ln earnings $\times$ Self-employment income

ln earnings ${ }^{2} \times$ Self-employment income 


\section{Table 4}

Estimates of linear probability models for same firm employment by fathers and sons: ever employed at the same firm as father

(1)
(2)

(3)

$(4)$

(5)

(6)

Father's Characteristics

$\begin{array}{lrrrrrr}\text { In } \text { earnings } & \mathbf{0 . 0 3 7} & \mathbf{- 1 . 1 3} & \mathbf{- 0 . 9 5 9} & \mathbf{- 0 . 6 4 8} & \mathbf{- 0 . 4 8 6} & \mathbf{- 0 . 7 3 1} \\ \text { In } \text { earnings }^{2} & & \mathbf{0 . 0 5 6 2} & \mathbf{0 . 0 4 8 4} & \mathbf{0 . 0 4 5 8} & \mathbf{0 . 0 4 3 1} & \mathbf{0 . 0 5 5 6} \\ & & & & & & \\ \text { Number of employers } & & & \mathbf{0 . 0 1 8 9} & \mathbf{0 . 0 0 6 7} & \mathbf{0 . 0 0 7 6} & \mathbf{0 . 0 0 7 5} \\ \text { Number of employers } & & & \mathbf{- 0 . 0 0 0 8 5} & \mathbf{- 0 . 0 0 0 5} & \mathbf{- 0 . 0 0 0 5} & \mathbf{- 0 . 0 0 0 5} \\ \text { Farming income } & & & 0.01032 & \mathbf{- 0 . 0 1 9 0} & \mathbf{- 0 . 0 1 9 2} & \mathbf{- 0 . 0 1 8 9} \\ \text { Fishing income } & & 0.00511 & 0.0320 & 0.0350 & 0.0329 \\ \text { Professional income } & & & \mathbf{- 0 . 0 8 2 9} & -0.0055 & -0.0146 & -0.0145 \\ \text { Self employment income } & & & \mathbf{0 . 0 5 9 3} & \mathbf{0 . 0 4 6 1} & \mathbf{0 . 0 4 7 6} & \mathbf{- 3 . 2 4 7} \\ & & & & & & \\ \text { Age } & \mathbf{0 . 0 1 1 9} & \mathbf{0 . 0 1 2 0} & \mathbf{0 . 0 1 2 5} & \mathbf{0 . 0 1 3 3} & \mathbf{0 . 0 1 4 6} & \mathbf{0 . 0 1 4 4} \\ \text { Age }^{2} / 10 & \mathbf{- 0 . 0 0 1 8} & \mathbf{- 0 . 0 0 1 9} & \mathbf{- 0 . 0 0 1 8 4} & \mathbf{- 0 . 0 0 1 8} & \mathbf{- 0 . 0 0 2 0} & \mathbf{- 0 . 0 0 1 9}\end{array}$

Firm and industry

characteristics

Firm Death

Firm size 1 to 10

Firm size 11 to 20

Firm size 21 to 50

Firm size 51 to 100

Firm size 101 to 500

Industry employment growth

Average years of schooling by two digit industry

Urban

Province / Region - number of indicators

Two digit industry indicators- number of indicators

$\begin{array}{rrr}\mathbf{- 0 . 0 5 7} & \mathbf{- 0 . 0 6 6} & \mathbf{- 0 . 0 6 5 4} \\ \mathbf{0 . 2 5 1} & \mathbf{0 . 0 8 7} & \mathbf{0 . 0 8 7} \\ \mathbf{0 . 1 7 1} & -0.0017 & -0.001 \\ \mathbf{0 . 1 8 3} & 0.0029 & 0.003 \\ \mathbf{0 . 1 6 6} & -0.0078 & -0.008 \\ \mathbf{0 . 1 0 1} & \mathbf{- 0 . 0 3 7} & \mathbf{- 0 . 0 3 7 8} \\ \mathbf{0 . 1 3 3} & \mathbf{0 . 1 5 8} & \mathbf{0 . 1 5 6} \\ \mathbf{0 . 1 1 7} & \mathbf{0 . 2 3 6} & \mathbf{0 . 2 3 6} \\ \mathbf{- 0 . 0 6 5} & \mathbf{- 0 . 0 6 1 1} & \mathbf{- 0 . 0 6 0 9} \\ 19 & 19 & 19 \\ & 75 & 75\end{array}$

Interactions

ln earnings $\times$ years industry average schooling

$-0.017$

$-0.0255$

$-0.0258$

ln earnings $\times$ Self-employment

income

$\ln$ earnings ${ }^{2} \times$ Self-employment

income

(1)

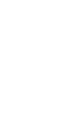

$\begin{array}{lrrrrrr}\text { Constant } & -0.125 & \mathbf{5 . 9 7} & \mathbf{4 . 9 1} & \mathbf{2 . 5 7} & \mathbf{1 . 1 0} & \mathbf{2 . 3 0} \\ \mathrm{R}^{2} & 0.0080 & 0.0116 & 0.0160 & 0.0792 & 0.1017 & 0.1025\end{array}$

Note: The dependent variable is defined to be a 0-1 indicator with the value of 1 indicating that the son was at employed at some point since the age of 16 with a firm that at some point in the past also employed his father. The analysis is based upon 70,99733 year old men, and information on their fathers. Boldface indicates results with t-statistics above 1.96, the analysis being based upon sample weights and robust calculations of standard errors. 
Table 5

Estimates of linear probability models for same firm employment by fathers and sons: main firm at 33 years of age same as father

(2)

(3)

(4)

(5)

(6)

Father's Characteristics

$\begin{array}{lrrrrrr}\text { In } \text { earnings } & \mathbf{0 . 0 2 7 7} & \mathbf{- 0 . 1 9 3} & \mathbf{- 0 . 3 1 7} & \mathbf{- 0 . 2 5 0} & \mathbf{- 0 . 2 4 2} & \mathbf{- 0 . 2 7 0} \\ \text { ln } \text { earnings }^{2} & & \mathbf{0 . 0 1 0 6} & \mathbf{0 . 0 1 5 9} & \mathbf{0 . 0 1 7 3} & \mathbf{0 . 0 1 7 5} & \mathbf{0 . 0 1 8 9} \\ \text { Number of employers } & & & & & & \\ \text { Number of employers } & & & \mathbf{- 0 . 0 2 0 3} & \mathbf{- 0 . 0 1 3 1} & \mathbf{- 0 . 0 1 3 0} & \mathbf{- 0 . 0 1 3 0} \\ & & & \mathbf{0 . 0 0 0 8 1} & \mathbf{0 . 0 0 0 4 8} & \mathbf{0 . 0 0 0 4 6} & \mathbf{0 . 0 0 0 4 6} \\ \text { Farming income } & & & & & & \\ \text { Fishing income } & & & 0.0004 & -0.0031 & -0.0030 & -0.0031 \\ \text { Professional income } & & & -0.0164 & -0.0122 & -0.0084 & -0.0086 \\ \text { Self employment income } & & & \mathbf{- 0 . 0 2 7 6} & -0.0057 & -0.0053 & -0.0054 \\ & & & \mathbf{0 . 0 0 7 2} & \mathbf{0 . 0 0 5 2} & \mathbf{0 . 0 0 5 4} & -0.5204 \\ \text { Age }_{\text {Age }^{2} / 10} & 0.00004 & 0.00001 & -0.00012 & 0.00041 & 0.00045 & 0.00048 \\ & -0.00008 & -0.00009 & -0.00015 & -0.00017 & -0.00018 & -0.00018\end{array}$

Firm and industry

characteristics

Firm Death

Firm size 1 to 10

Firm size 11 to 19

Firm size 21 to 50

Firm size 51 to 100

Firm size 101 to 500

$\begin{array}{rrr}\mathbf{- 0 . 1 3 6} & \mathbf{- 0 . 1 4 3} & \mathbf{- 0 . 1 4 3} \\ \mathbf{0 . 0 7 9 3} & \mathbf{0 . 0 3 2 0} & \mathbf{0 . 0 3 1 9} \\ \mathbf{0 . 0 2 2 9} & \mathbf{- 0 . 0 2 0 9} & \mathbf{- 0 . 0 2 1 0} \\ \mathbf{0 . 0 1 8 0} & \mathbf{- 0 . 0 2 7 6} & \mathbf{- 0 . 0 2 7 6} \\ \mathbf{0 . 0 1 3 9} & \mathbf{- 0 . 0 2 8 8} & \mathbf{- 0 . 0 2 8 8} \\ \mathbf{0 . 0 1 5 0} & \mathbf{- 0 . 0 2 5 0} & \mathbf{- 0 . 0 2 5 0} \\ & & \\ \mathbf{0 . 0 7 1 8} & 0.0161 & 0.0161 \\ \mathbf{0 . 0 5 8 1} & \mathbf{0 . 0 8 3 8} & \mathbf{0 . 0 8 4 7} \\ \mathbf{- 0 . 0 1 1 6} & \mathbf{- 0 . 0 1 3 7} & \mathbf{- 0 . 0 1 3 7} \\ 19 & 19 & 19 \\ & 75 & 75\end{array}$

Industry employment growth

Average years of schooling by two digit industry

Urban

Province / Region - number of indicators

Two digit industry indicators - number of indicators

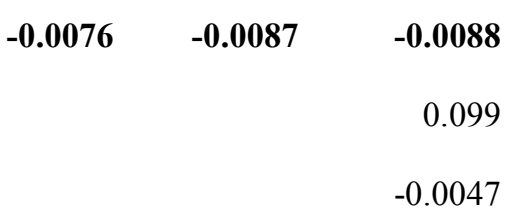

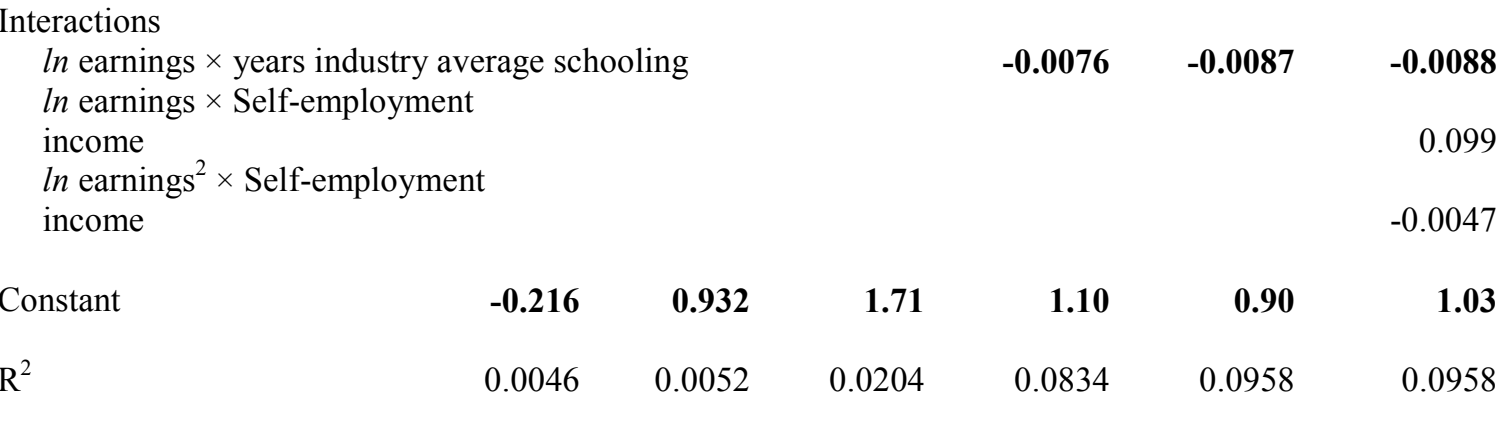

Note: The dependent variable is defined to be a $0-1$ indicator with the value of 1 indicating that the son's main employer at age 33 is the same as the father's main employer when the son was 15 to 19 years of age. The analysis is based upon 70,997 men, and information on their fathers. Boldface indicates results with t-statistics above 1.96, the analysis being based upon sample weights and robust calculations of standard errors. 
Table 6

Alternative specifications of linear probability models for same firm employment by fathers and sons: ever employed at the same firm as father

\begin{tabular}{|c|c|c|c|c|}
\hline & $\begin{array}{c}\text { Original } \\
\text { specification } \\
\text { column (6) } \\
\text { Table } 4\end{array}$ & $\begin{array}{c}\text { Rural } \\
\text { subsample }\end{array}$ & $\begin{array}{c}\text { Urban } \\
\text { subsample }\end{array}$ & $\begin{array}{l}\text { Paternal } \\
\text { market } \\
\text { income } \\
\text { rather than } \\
\text { earnings } \\
\end{array}$ \\
\hline \multicolumn{5}{|l|}{ Father's Characteristics } \\
\hline ln earnings & -0.731 & -0.705 & -0.551 & -0.694 \\
\hline $\ln$ earnings $^{2}$ & 0.0556 & $\mathbf{0 . 0 5 7 0}$ & 0.0505 & $\mathbf{0 . 0 5 7 5}$ \\
\hline Number of employers & 0.0075 & 0.0136 & 0.0047 & 0.0103 \\
\hline Number of employers $^{2}$ & -0.0005 & -0.0007 & -0.0003 & -0.0005 \\
\hline Farming income & -0.0189 & -0.0447 & 0.0299 & -0.0181 \\
\hline Fishing income & 0.0329 & 0.0324 & -0.0058 & 0.0336 \\
\hline Professional income & -0.0145 & -0.0681 & -0.0096 & -0.0399 \\
\hline Self employment income & -3.247 & -3.555 & -2.965 & -5.023 \\
\hline In earnings $\times$ Self-employment income & 0.682 & 0.745 & 0.624 & 1.00 \\
\hline $\ln$ earnings ${ }^{2} \times$ Self-employment income & -0.0349 & -0.038 & -0.0320 & -0.0493 \\
\hline $\mathrm{R}^{2}$ & 0.1025 & 0.1348 & 0.0941 & 0.1101 \\
\hline Number of observations & 70,997 & 15,817 & 55,180 & 70,980 \\
\hline
\end{tabular}

Note: The dependent variable is defined to be a $0-1$ indicator with the value of 1 indicating that the son was employed at some point since the age of 16 with a firm that at some point in the past also employed his father. Rural subsample refers to those father-son observations with fathers having lived in rural areas, those with a second digit of the postal code equal to zero, and Urban subsample to those living in urban areas, with a second digit of the postal code not equal to zero. Boldface indicates results with t-statistics above 1.96 , the analysis being based upon sample weights and robust calculations of standard errors. The coefficient on the presence of selfemployment income in the rural subsample is statistically significant at the $10 \%$ level, with p-value of 0.052 . The specification for the last column is based upon total parental market income in all cases, not earnings. All models include the remaining covariates reported in column (6) table 5. 
Table 7

Alternative specifications of linear probability models for same firm employment by fathers and sons: main firm at 33 years of age same as father

\begin{tabular}{|c|c|c|c|c|}
\hline & $\begin{array}{c}\text { Original } \\
\text { specification } \\
\text { column (6) } \\
\text { Table } 5\end{array}$ & $\begin{array}{c}\text { Rural } \\
\text { subsample }\end{array}$ & $\begin{array}{c}\text { Urban } \\
\text { subsample }\end{array}$ & $\begin{array}{l}\text { Paternal } \\
\text { market } \\
\text { income } \\
\text { rather than } \\
\text { earnings }\end{array}$ \\
\hline \multicolumn{5}{|l|}{ Father's Characteristics } \\
\hline ln earnings & -0.270 & -0.306 & -0.339 & -0.306 \\
\hline $\ln$ earnings ${ }^{2}$ & 0.0189 & 0.0218 & 0.0229 & $\mathbf{0 . 0 2 3 7}$ \\
\hline Number of employers & -0.0130 & -0.0137 & -0.0128 & -0.0118 \\
\hline Number of employers $^{2}$ & 0.00046 & 0.0005 & 0.00045 & 0.00043 \\
\hline Farming income & -0.0031 & -0.0061 & 0.0052 & -0.00017 \\
\hline Fishing income & -0.00086 & 0.0012 & -0.0257 & -0.0048 \\
\hline Professional income & -0.0054 & -0.0316 & -0.0040 & -0.0141 \\
\hline Self employment income & -0.5204 & -0.911 & -0.637 & -1.796 \\
\hline ln earnings $\times$ Self-employment income & 0.099 & 0.182 & 0.122 & 0.338 \\
\hline ln earnings ${ }^{2} \times$ Self-employment income & -0.0047 & -0.009 & -0.0057 & -0.016 \\
\hline $\mathrm{R}^{2}$ & 0.0958 & 0.1356 & 0.0867 & 0.1018 \\
\hline Number of observations & 70,997 & 15,817 & 55,180 & 70,980 \\
\hline
\end{tabular}

Note: The dependent variable is defined to be a $0-1$ indicator with the value of 1 indicating that the son's main employer at 33 is the same as the father's main employer when the son was 15 to19 years of age. Rural subsample refers to those father-son observations with fathers having lived in rural areas, those with a second digit of the postal code equal to zero, and Urban subsample to those living in urban areas, with a second digit of the postal code not equal to zero. Boldface indicates results with t-statistics above 1.96, the analysis being based upon sample weights and robust calculations of standard errors. The specification for the last column is based upon total parental market income in all cases, not earnings. All models include the remaining covariates reported in column (6) table 6. 
Table 8

Alternative specifications of the linear regression to the mean model of intergenerational earnings transmission using information on the son ever being employed at the same employer as the father

(1)

(2)

(3)

(4)

\begin{tabular}{lcccr}
\hline In father's earnings & 0.250 & 0.198 & 0.199 & 0.185 \\
In father's earnings $\times$ Same Firm & & 0.113 & 0.105 & 0.105 \\
& & & & -1.08 \\
Same Firm & & -1.15 & -1.09 & 0.109 \\
Same Industry & & & 0.095 & -0.160 \\
Same Region & 7.50 & 8.02 & 7.99 & 8.20 \\
Constant & 0.0485 & 0.0518 & 0.0553 & 0.0741 \\
Adjusted $\mathrm{R}^{2}$ & & & & \\
\hline
\end{tabular}

Note: Table entries are least squares coefficients based upon the model described in the text. The dependent variable is the three year average of son's log earnings. Father's earnings are measured as a five-year average, and the father's age and age squared are also included as regressors. All estimates are statistically significant with t-statistics of at least 8.72. 
Table 9

Alternative specifications of the linear regression to the mean model of intergenerational earnings transmission using information on the son having the same main employer as the father

\begin{tabular}{lcccr}
\hline & $(1)$ & $(2)$ & $(3)$ & $(4)$ \\
\hline In father's earnings & 0.250 & 0.235 & 0.235 & 0.221 \\
In father's earnings $\times$ Same Firm & & 0.177 & 0.178 & 0.174 \\
$\quad$ Same Firm & & -1.68 & -1.73 & -1.66 \\
$\quad$ Same Industry & & & 0.035 & 0.041 \\
Same Region & & & & -0.163 \\
Constant & 7.50 & 7.65 & 7.64 & 7.85 \\
Adjusted $\mathrm{R}^{2}$ & 0.0485 & 0.0561 & 0.0572 & 0.0766 \\
\hline
\end{tabular}

Note: Table entries are least squares coefficients based upon the model described in the text. The dependent variable is the three year average of son's log earnings. Father's earnings are measured as a five-year average, and the father's age and age squared are also included as regressors. All estimates are statistically significant with t-statistics of at least 4.39. 
Figure 1

Proportion of sons employed currently or at some point in the past with an employer their fathers had worked for at any time in the past

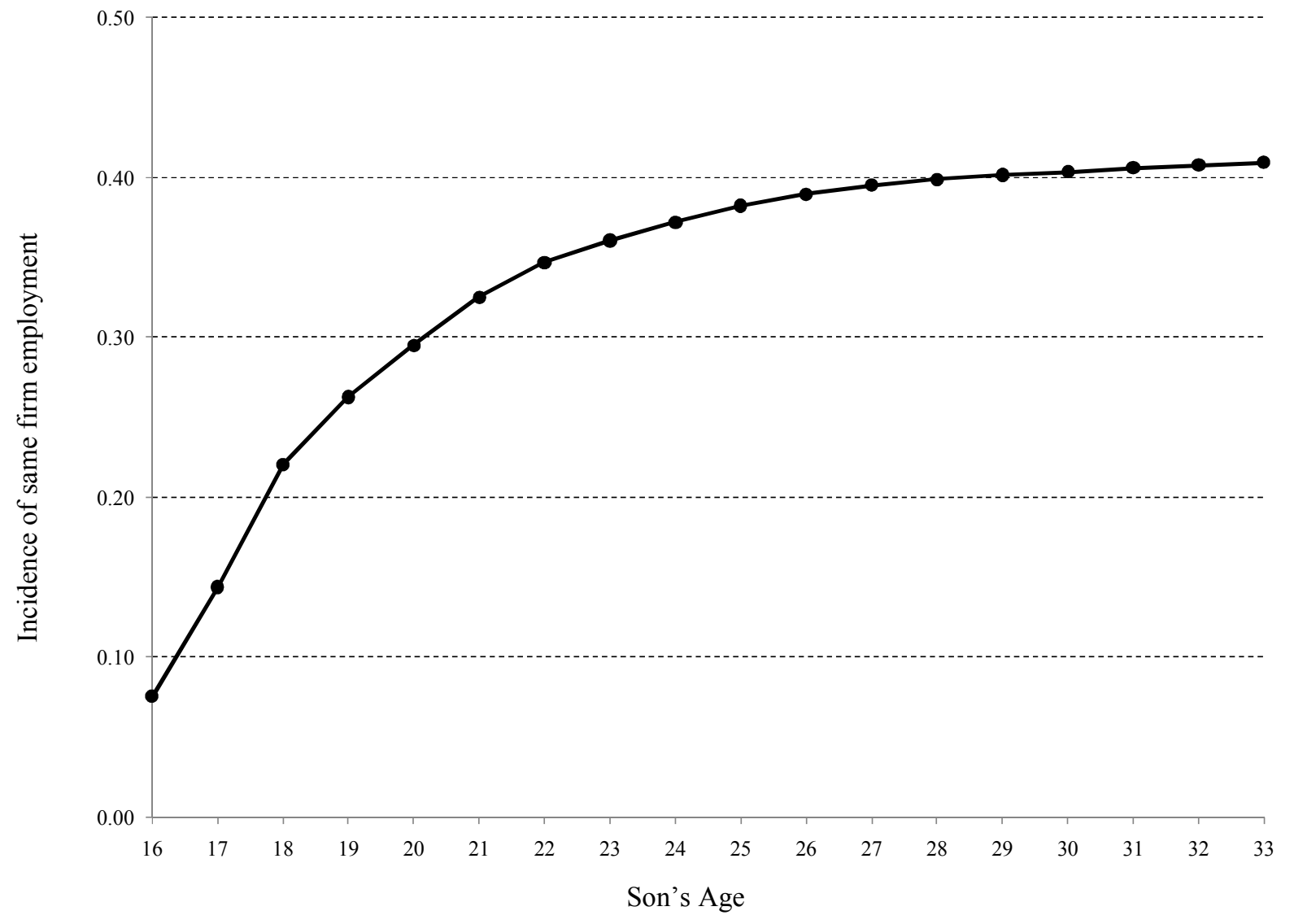

Note: Calculations are based on weighted observations of 71,215 sons who are all 33 years of age at the end of our observation period, 1996. 
Figure 2

Proportion of sons employed currently or at some point in the past with an employer their fathers had worked for at any time in the past for each percentile of the father's earning distribution

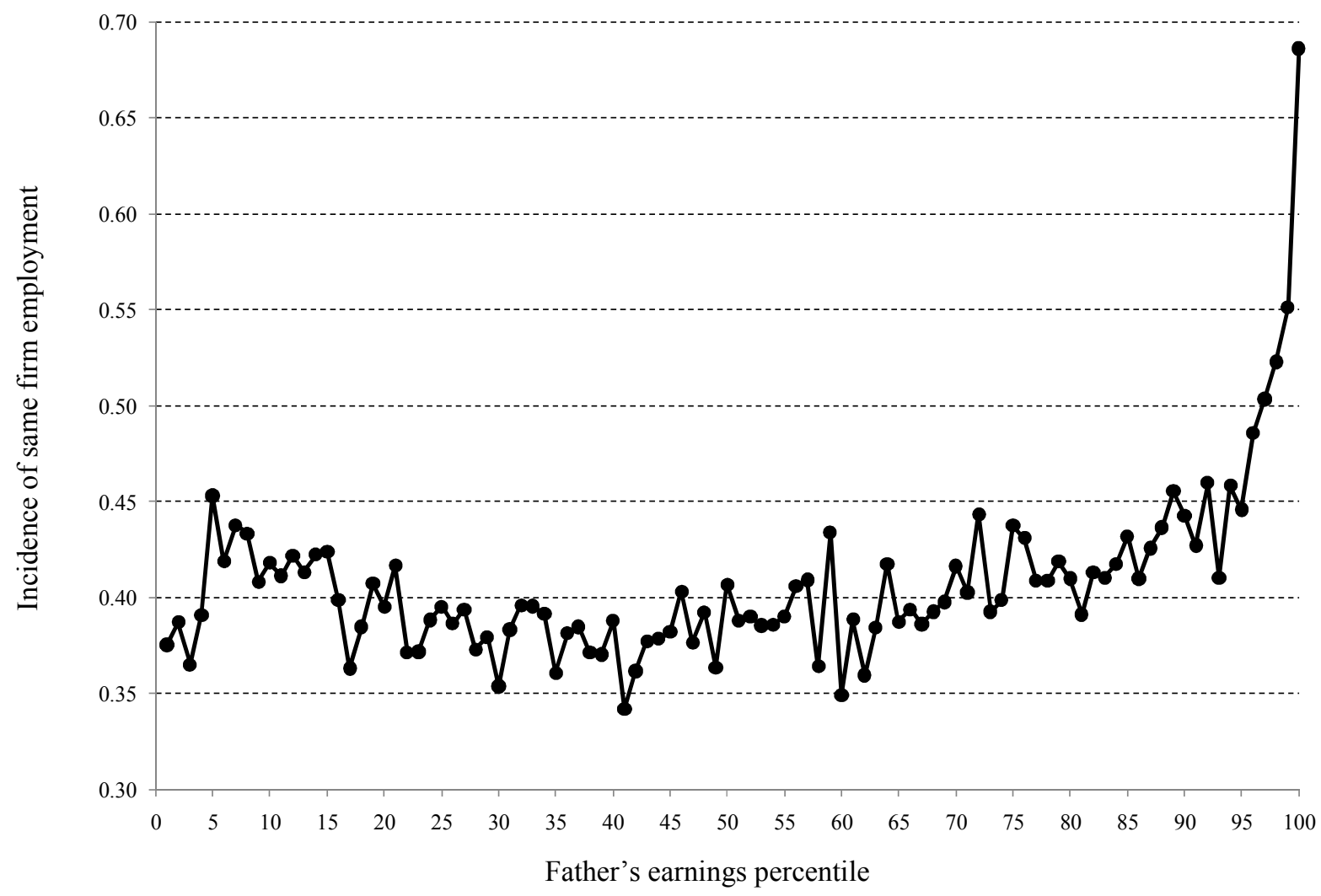

Note: Calculations are based on weighted observations of 71,215 sons who are 33 years of age. Father's earnings percentiles are calculated using a five year average of earnings during the period sons were 15 to 19 years of age. On average fathers are 45.3 years old at the onset of this period. 
Figure 3

Intergenerational earnings elasticities estimated using nearest neighbourhood estimation according to whether 33 year old sons ever had the same employer as their father or not

A. Never same employer

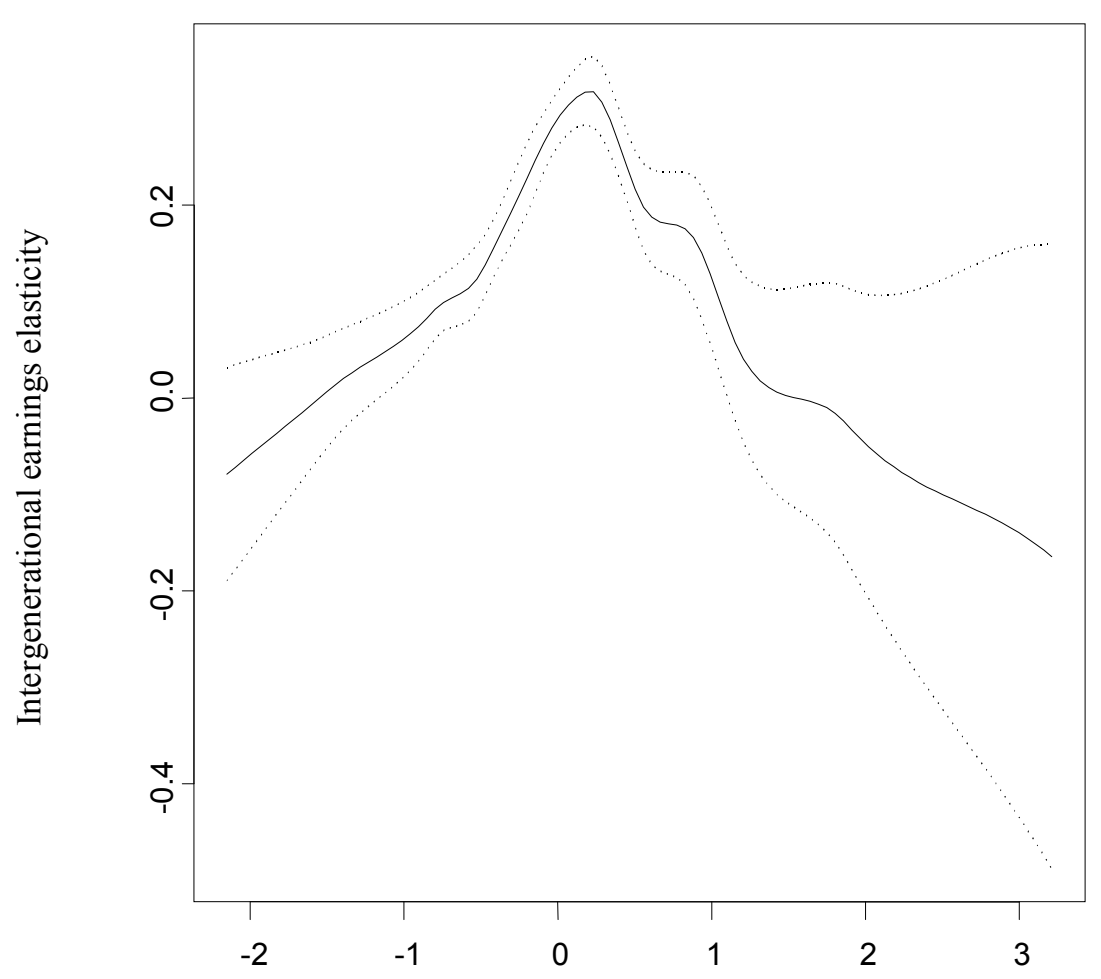

Father's age adjusted $\ln$ earnings (standardized)
B.Same employer at some point in past

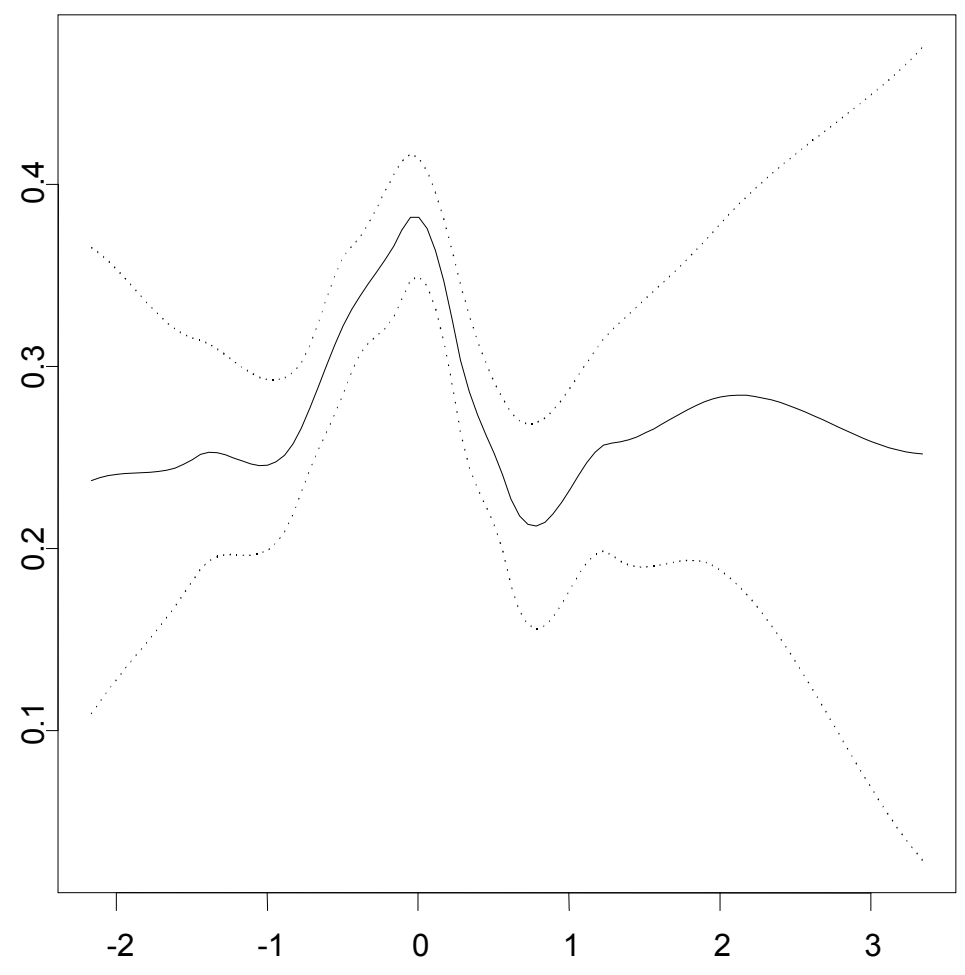

Father's age adjusted $\ln$ earnings (standardized) 
Figure 4

Intergenerational earnings elasticities estimated using nearest neighbourhood estimation according to whether 33 year old sons had the same main employer as their father or not

A. Never same employer

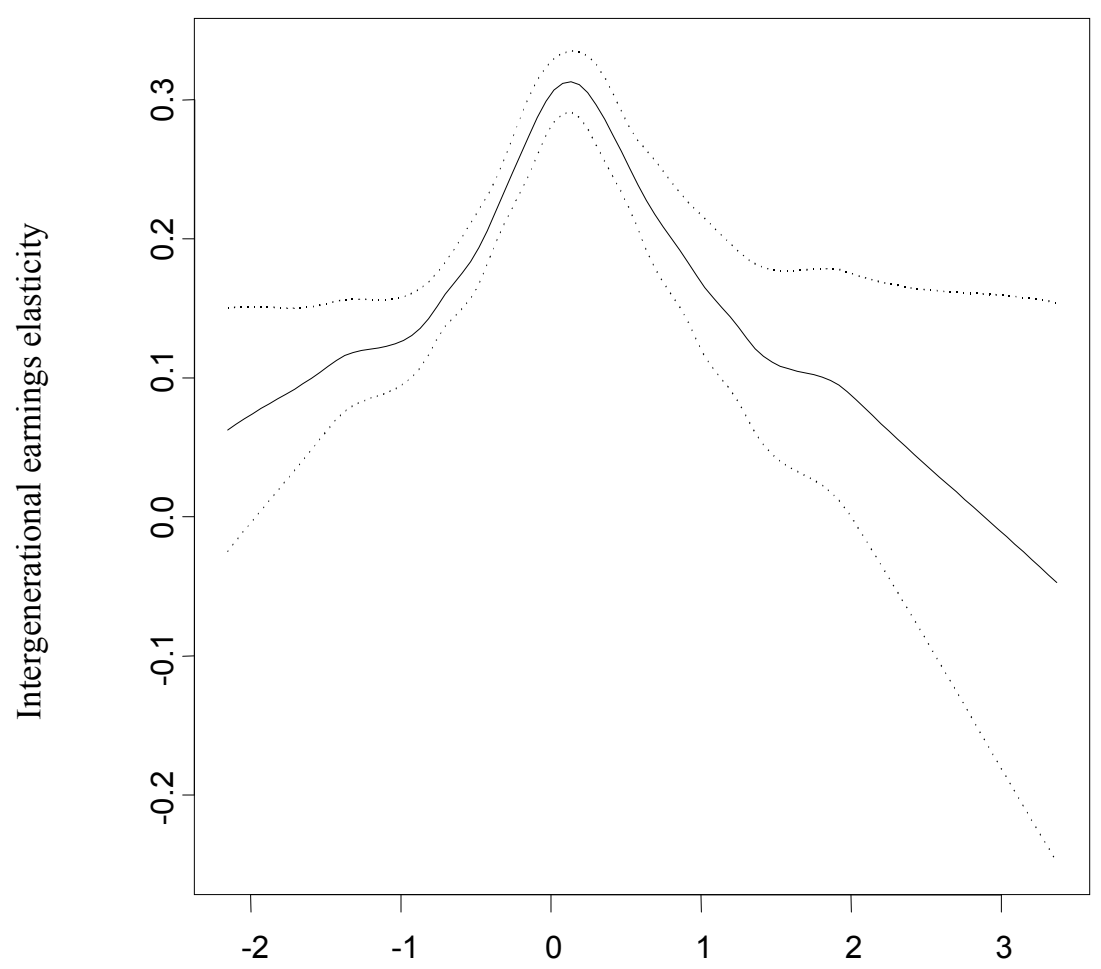

Father's age adjusted $\ln$ earnings (standardized)
B. Same main employer

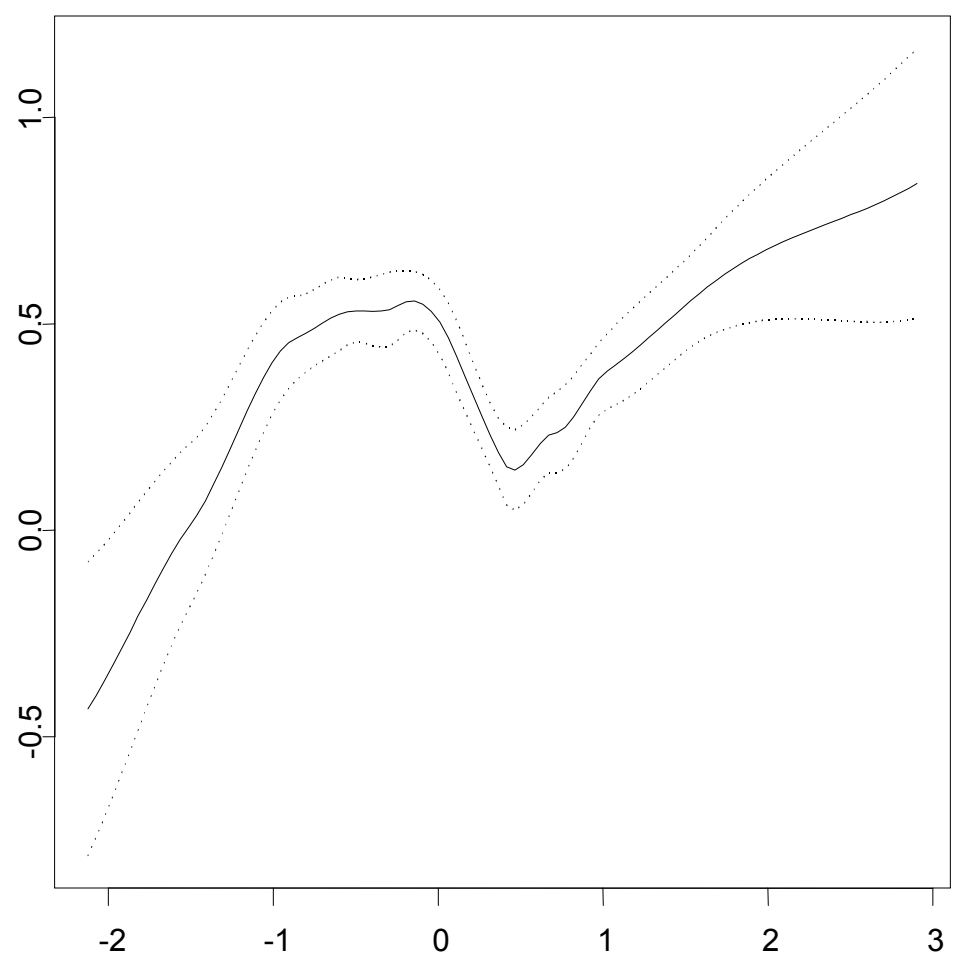

Father's age adjusted $\ln$ earnings (standardized) 